\title{
USULAN PENGEMBANGAN SISTEM BALITAROT UNTUK MENDUKUNG PERENCANAAN BERKELANJUTAN
}

\author{
Andreas Febrian dan Aniati Murni \\ Fakultas Ilmu Komputer, Universitas Indonesia, Kampus UI Depok, Jawa Barat, 16424, Indonesia \\ E-mail: andreas.febrian@ui.ac.id
}

\begin{abstract}
Abstrak
Sistem pemerintahan di Indonesia pada saat ini masih berbasis kerja manual. Mekanisme ini mengakibatkan pembangunan di beberapa wilayah terabaikan. Selain itu, metode ini sering tidak didukung dengan standar pengerjaan yang jelas. Salah satu efek yang dirasakan adalah kurang terpenuhinya kebutuhan masyarakat. Permasalahan yang berbeda muncul di wilayah yang sudah dibangun dengan pesat. Pada daerah ini pengawasan dan peremajaan fasilitas yang sudah dibangun jarang sekali dilakukan. Hal ini memperpendek umur fasilitas tersebut. Hal-hal tersebut disebabkan karena perencanaan yang kurang matang dan tidak adaptif terhadap waktu. Penelitian ini mengusulkan sebuah sistem yang bernama Sistem BALITAROT (Perbaikan Lingkungan dan Tata Ruang Kota). Sistem ini dapat membantu pemerintah dan instansi terkait dalam menentukan kebijakan mengenai perbaikan lingkungan dan tata ruang kota.
\end{abstract}

Kata kunci: sistem informasi geografis, perencanaan wilayah, perencanaan berkelanjutan

\begin{abstract}
Government system in Indonesia is still based on manual work. These mechanisms lead to the development in some neglected areas. In addition, this method is often not supported by clear standards of work man ship. One effect that is felt is failed to fulfill community needs. Different problems arise in areas that have been built at a rapid pace. In this area, supervision and rejuvenation of facilities that already built is rarely done. It is shortening the life span of the facility. Those things are caused by unfinished planning and not adaptive to time. This study proposes a system called System BALITAROT (Restoration of Environment and City Layout). This system can help governments and relevant agencies in determining policy on environmental improvement and city layout.
\end{abstract}

Keywords: geographic information systems, spatial planning, sustainable planning

\section{Latar Belakang}

Indonesia adalah sebuah negara yang luas, kaya akan sumber daya alam, dan memiliki tingkat populasi yang tinggi. Luas wilayah darat Indonesia diperkirakan sebesar $1.919 .440 \mathrm{~km}^{2}[1]$. Pemerintah Indonesia telah berhasil melakukan pembangunan hampir diseluruh wilayah walau kecepatan pembangunannya tidak seimbang. Beberapa daerah di Indonesia sangat pesat pembangunannya, sedangkan di daerah lainnya tidak. Indonesia terbagi menjadi 33 propinsi [2]. Gambar 1 menunjukkan pembagian propinsi di Indonesia. Setiap propinsi dipimpin oleh satu orang gubernur. Gubernur dibantu oleh bupatibupati yang mengatur wilayah yang lebih kecil. Pembagian tanggung jawab ini terus berlanjut sampai tingkat kecamatan.

Model pemerintahan bertingkat memungkinkan terjadinya pembangunan yang merata dan pesat diberbagai daerah. Disayangkan model seperti ini juga memungkinkan terjadinya penyalahgunaan kekuasaan, seperti pendirian bangunan yang tidak sesuai dengan aturan tata ruang kota. Kasus Situ Gintung contohnya, pembangunan perumahan tepat pada aliran air waduk yang termasuk daerah berbahaya untuk dibuka sebagai daerah hunian.

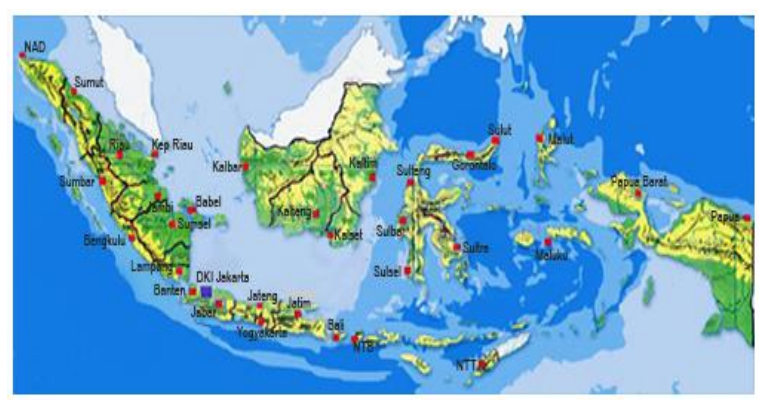

Gambar 1. Peta Republik Indonesia [2]. 
Kasus lainnya adalah pembangunan di Ibu Kota Negara. Pembangunan di Jakarta terlihat seperti tidak memiliki pedoman tata ruang kota. Jakarta memiliki daerah-daerah yang rawan banjir walau hanya tersiram hujan sedikit saja. Hal ini menunjukkan kurangnya perencanaan yang matang dalam penataan ruang kota.

Pembangunan paling pesat di Indonesia dapat dilihat di pulau Jawa, Sumatra, dan Bali. Sebagian kota di pulau-pulau tersebut memiliki tata ruang kota yang kurang baik. Hal ini mengakibatkan kota tersebut rapuh terhadap kejadian-kejadian alam seperti gempa bumi atau hujan. Banjir yang disebabkan air hujan yang tidak dapat diserap oleh tanah kemudian mengambang dipermukaan tanah. Hal ini diperburuk oleh perubahan gaya hidup yang mengubah peran tanah sebagai penghasil makanan menjadi tempat tinggal atau kantor. Perubahan ini merupakan salah satu penyebab Indonesia tidak dapat memenuhi kebutuhan pangan warganya.

Paling tidak ada dua kemungkinan yang menyebabkan tidak teraturnya pembangunan. Pertama karena tidak adanya tata ruang yang dapat diikuti dalam pembangunan kota. Kedua adalah ketidakpatuhan aparatur negara dalam mengikuti aturan yang sudah dikeluarkan, termasuk aturan tata ruang. Ada juga kecenderungan untuk tidak memelihara dan meremajakan hasil pembangunan. Hal ini dapat dilihat dari banyaknya fasilitas-fasilitas yang disediakan negara, rusak atau tidak layak pakai. Seperti yang terlihat pada gambar 2, kondisi salah satu jembatan penyebrangan di daerah Sudirman. Warga Indonesia juga kurang mampu menghargai pembangunan yang telah dilakukan. Banyak hasil pembangunan yang dengan mudah dihancurkan ketika berdemonstrasi. Pagar dirobohkan agar dapat menyebrang tanpa harus menggunakan jembatan penyebrangan. Kendaraaan bermotor juga sering menggunakan jembatan penyebrangan untuk memotong jalan atau berputar. Hal tersebut akhirnya memperpendek umur sarana yang telah dibangun.

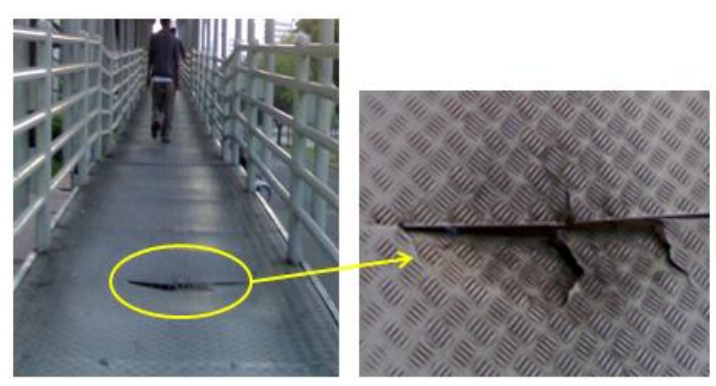

Gambar 2. Jembatan yang sudah rusah di daerah Sudirman.
Pemerintah Indonesia sampai saat ini masih berusaha untuk memenuhi kebutuhan warganya dan terus melakukan perbaikan. Perbaikan yang dilakukan diantaranya adalah membangun fasilitas untuk memenuhi kebutuhan masyarakat dan meningkatkan kualitas aparatur negara dalam memberikan layanan kepada masyarakat. Beranjak dari hal tersebut, penelitian ini mengusulkan pembuatan sistem yang dapat membantu pemerintah dalam menentukan kebijakan yang terkait dengan perbaikan lingkungan dan tata ruang kota. Sistem yang diusulkan diberi nama Sistem Perbaikan Lingkungan dan Tata Ruang Kota (BALITAROT). Pengembangan dan pemanfaatan sistem ini membutuhkan kerjasama instansiinstansi pemerintah, organisasi-organisasi independen, dan masyarakat umum.

Sistem BALITAROT dikembangkan untuk membantu pemerintah dalam menentukan kebijakan dan pengawasan terkait tata ruang kota. Beberapa hal yang diharapkan dapat diakomodir dengan adanya pengembangan sistem ini adalah: (1) Penyediaan data spasial wilayah Indonesia untuk dimanfaatkan oleh pemerintah, lembaga independen, dan khalayak umum. (2) Penyediaan data non-spasial seperti jumlah penduduk, luas wilayah pendapatan rata-rata, dan fasiltas yang tersedia. (3) Pendataan fasilitas dan layanan yang dibutuhkan masyarakat. (4) Pengawasan terhadap tingkat terpenuhinya fasilitas dan layanan minimal yang dibutuhkan masyarakat pada suatu daerah. (5) Penyebaran informasi-informasi penting bagi masyarakat dan aparatur pemerintah. (6) Memberikan perlindungan terhadap sumber daya alam dan budaya yang dimiliki Indonesia. (7) Membantu dalam perencanaan atau perbaikan tata ruang kota. Sistem juga dapat dimanfaatkan untuk melakukan perencanaan daerah yang kurang berkembang. (8) Memberikan masukan untuk perbaikan lingkungan, seperti yang sedang berlangsung di Korea [3]. (9) Pengawasan dan pemeliharaan fasilitas yang sudah dibangun. Pengawasaan juga dapat dilakukan dengan memanfaatkan kamera dan informasi dari masyarakat seperti yang diusulkan dalam [4]. (10) Membantu dalam perancangan strategi pengendalian dan penyelamatan jika terjadi bencana alam seperti yang diusulkan di [5]. (11) Mempermudah kolaborasi antar instansi terkait dalam menentukan kebijakan tata ruang dan perbaikan lingkungan.

Sistem ini diharapkan menjadi sistem yang menyediakan serta memanfaatkan data spasial dan data non-spasial Indonesia. Pengguna sistem dapat bekerja secara visual menggunakan data spasial tersebut. Data spasial dapat berupa foto, 
peta, atau pencitraan satelit.

\section{Metodologi}

Pengembangan Sistem BALITAROT dapat memanfaatkan penelitian-penelitian yang dilakukan sebelumnya. Penelitian yang dilakukan oleh Sun-Kee Hong, In-Ju Song, dan Jianguo Wu [3] mengenai perbaikan lingkungan. Penelitian yang dilakukan Mohamad Ali Fulazzaky dan Hilman Akil [4] yang membahas manajemen sumber daya air di Indonesia. Penelitian Nabil Sahli dan Bernard Moulin [5] yang mengedepankan konsep perencanaan berkelanjutan (ContinualPlanning). Beberapa konsep dalam tiga penelitian tersebut dapat diadaptasi untuk pengembangan BALITAROT.

Perbaikan lingkungan: Indonesia terkenal sebagai wilayah yang subur dan makmur. Indonesia juga memiliki banyak kekayaan alam dan budaya yang menarik. Namun disayangkan banyak kekayaan alam Indonesia yang rusak, seperti kondisi tanah di Sidoarjo, hutan-hutan di Kalimantan, dan terumbu karang di Maluku. Salah satu penyebab kerusakan tersebut adalah kurangnya perhatian dan pengawasan pemerintah. Kurangnya kesadaran warga Indonesia mengenai pentingnya menjaga kekayaan dan secara aktif memperburuk kerusakan yang ada. Salah satu hal yang dilakukan warga adalah mengkonsumsi yang tidak perlu sehingga menimbulkan sampah plastik dan elektronik. Hal ini penting karena Indonesia masih kesulitan untuk mengurus produksi sampahnya. Hal ini menunjukkan bahwa agenda perbaikan lingkungan layak menjadi prioritas. Selain itu, usaha untuk mengubah pola pikir masyarakat juga harus digalakkan.

Makalah [3] dengan judul "Fengshui Theory in Urban LandscapePlanning" membahas rencana perbaikan lingkungan di Korea dengan berpedoman pada prinsip fung shui. Sejarah menunjukkan bahwa pembangunan di Korea sejak dahulu selalu mengikuti prinsip fung shui. Namun dalam beberapa tahun terakhir budaya tersebut sudah tidak lagi diikuti. Hal ini disebabkan oleh bertambahnya jumlah penduduk dan semakin sedikitnya lahan kosong di Korea.

Berbicara mengenai fung shui, fung shui melihat dunia dari kacamata energi kosmis. Segala sesuatu di dunia memiliki energi dan setiap energi ini ingin bergerak dengan bebas. Aliran energi ini dikenal dengan nama Qi. Fung shui memberikan petunjuk untuk mengatur susunan benda atau bangunan sehingga energi dapat mengalir dengan bebas [6]. Fung shui percaya bahwa dengan mengerti aliran energi ini dapat membantu manusia agar dapat hidup lebih harmonis dengan alam. Penggunaan alat-alat untuk memperkirakan dan memanfaatkan pergerakan aliran energi bukanlah hal yang tidak mungkin. Salah satu alat yang umum dikenal adalah $B a-G u a$.

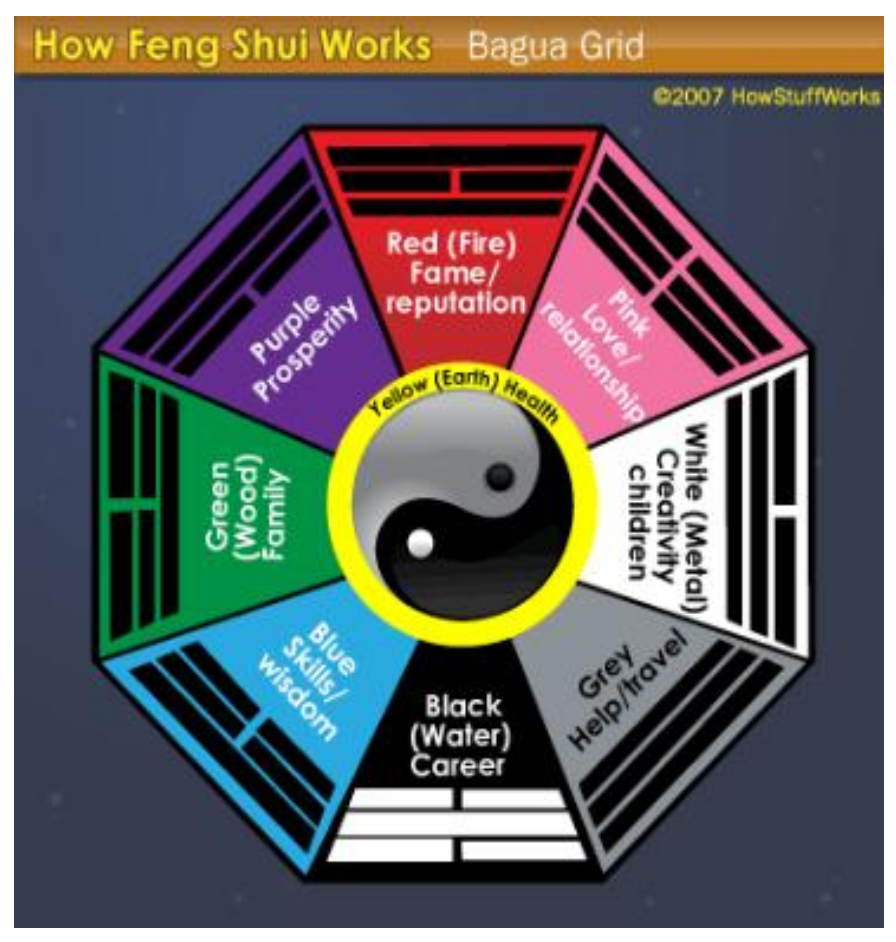

Gambar 3. Ba-Gua [6]. 
Pada gambar 3 dapat dilihat bahwa $B a-G u a$ dibagi menjadi beberapa bagian. Setiap bagian merepresentasikan salah satu aspek kehidupan seperti karir, kebijaksanaan, keluarga, reputasi, hubungan, dan kesehatan. Bagian berwarna hitam selalu berhimpitan dengan tembok di mana pintu masuk berada. Berdasarkan patokan ini, pembacaan aliran dalam ruangan dilakukan. Penafsiran dan perbaikan antara satu ahli fung shui dengan yang lainnya tidak selalu sama, kepercayan, dan pengalaman akan mempengaruhi pandangan mereka. Cara penggunaan Ba-Gua yang lebih lengkap dapat dilihat pada [6].

Penggunaan fung shui sering sekali dihubungkan dengan tahayul. Hal ini merupakan kesalahpahaman yang cukup mengakar. Fung shui memang dapat dipandang sebagai kolaborasi antara kebudayaan dan kepercayaan, namun prinsip dibaliknya merupakan hasil pengamatan selama beratus-ratus tahun. Hanya saja aliran energi pada fung shui tetap tidak dapat dianggap sebagai ilmu pengetahuan karena tidak dapat dibuktikan secara empiris.

Pemerintah Korea melakukan perbaikan lingkungan dengan memperbaiki aliran $Q i$. Perbaikan dapat dilakukan jika peta yangmenggambarkan aliran pergerakan $Q i$ tersedia. Peta ini disebut peta kognitif. Peta kognitif dibuat berdasarkan hasil pengamatan dan analisa menggunakan gambar-gambar dari daerah yang ingin diamati aliran $Q i$-nya. Peta kognitif untuk Korea dapat dilihat pada gambar 4. Ada dua cara untuk memperbaiki aliran $Q i$. Pertama adalah
Bibo, yaitu memperkuat susunan atau struktur objek-objek yang ada. Kedua adalah Apseung, yaitu menghilangkan objek-objek yang tidak perlu atau menggangu aliran $Q i$. Hal ini juga dapat berarti menghilangkan daerah terbuka dengan membangun sesuatu pada daerah tersebut. Kegiatan membersihkan sampah yang menggangu aliran air sungai merupakan kegiatan yang sesuai dengan konsep Apseung dalam fung shui.Daerah yang diberi warna hijau muda dan biru muda dikembalikan fungsinya sehingga aliran $Q i$ lancar. Warna hijau muda berarti daerah hijau sedangkan warna biru berarti daerah aliran air. Teknik perbaikan akan bergantung pada kondisi lingkungan. Tabel I memperlihatkan cara pandang fung shui pada suatu lingkungan. Tujuan perbaikan ini adalah mengubah energi negatif menjadi energi positif. Makalah [3] menunjukkan bahwa cara yang digunakan fung shui dalam memperbaiki aliran $Q i$ sesuai dengan prinsip perbaikan lingkungan saat ini.

Korea juga merencanakan mengubah struktur kota Seoul mengikuti konsep kota satelit. Gambar 5 memperlihatkan model kota yang ingin dibangun. Pembangunan kota satelit juga memanfaatkan prinsip prinsip fung shui. Fung shui dimanfaatkan agar setiap kota satelit memiliki aliran energi yang baik dan tidak mengganggu daerah disekitarnya. Konsep kota satelit juga pernah ingin diterapkan untuk Jakarta, namun tidak berhasil. Informasi lebih lengkap mengenai proyek perbaikan di Korea dapat dilihat di [7].

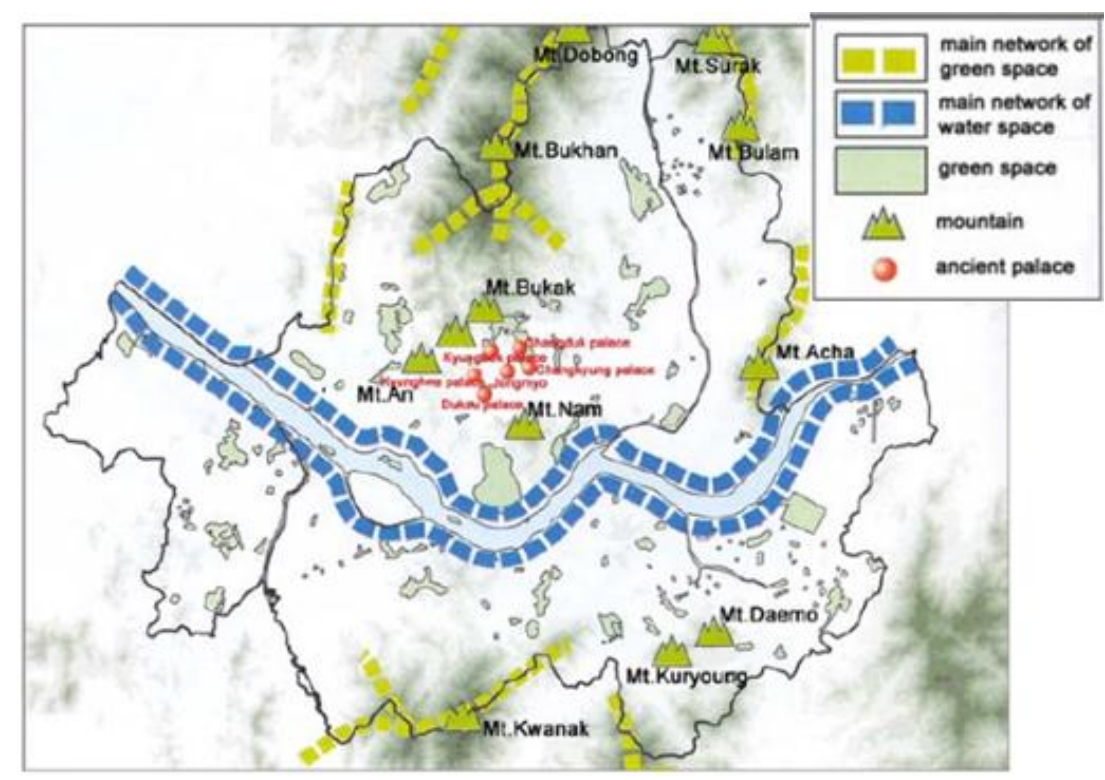

Gambar 4. Peta kognitif untuk perbaikan $Q i$ di Korea [3] 


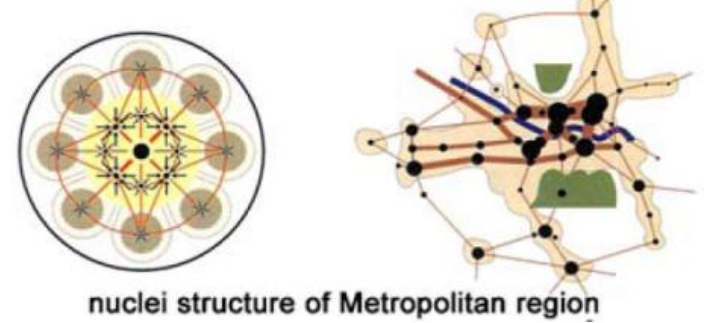

Gambar 5. Pengembangan kota satelit di Seoul [3].

Informasi yang ada pada makalah fung shui ini dijadikan panduan dan catatan bagi pengguna sistem dalam pengambilan keputusan. Sistem akan menyimpan teknik perbaikan lingkungan yang dibahas dalam [3]. Manfaat informasi ini dapat dirasakan dalam proses perancangan tata ruang atau perbaikan lingkungan. Misalnya pada pembangunan tata ruang kota di wilayah baru, sistem dapat memberikan daftar sarana dan prasarana minimum yang harus dimiliki oleh kota tersebut. Sistem juga dapat memberikan saran untuk perbaikan dan pelestarian lingkungan. Informasi yang tersimpan dalam sistem akan serupa seperti data pada tabel I.

Pengembangan Sistem Manajemen Sumber Daya Air: Mohamad Ali Fulazzaky dan Hilman Akil dalam [4] mengusulkan sebuah sistem untuk membantu manajemen sumber daya air di Indonesia. Sistem ini menggunakan data spasial dan data non-spasial (teks). Data spasial berupa data struktur saluran air bawah dan atas tanah. Hal ini diharapkan dapat membantu perencanaan nasional pada bidang sumber daya air di masa yang akan datang. Data teks yang disimpan seperti peraturan, regulasi, dan data institusi. Sistem ini diharapkan dapat menyimpan skema irigasi, lokasi sumber air, dan lokasi pengumpulan data air. Sistem juga dapat digunakan untuk pengawasan potensi banjir atau kekeringan.

Sistem manajemen sumber daya air diharapkan dapat membantu banyak pihak. Pihak yang bertindak sebagai pengguna juga diharapkan menjadi penyedia data. Pengguna-pengguna sistem ini adalah Direktorat Sumber Daya Air, pemerintah pusat, pemerintah daerah, organisasi independen, universitas, dan institusi-institusi terkait. Seluruh pengguna diharapkan dapat membantu dalam penyediaan, pengawasan, dan perbaikan pengaturan sumber daya air di Indonesia. Konsep yang diajukan memang membutuhkan partisipasi aktif dari berbagai pihak, namun jika dapat dijalankan maka akan memberikan manfaat yang sangat besar.

Desain BALITAROT mengadopsi banyak konsep yang digunakan dalam pengembangan sitem manajemen sumber daya air. Beberapa diantaranya adalah pemanfaatan data spasial dan non-spasial secara bersamaan dan pemanfaatan data yang sudah ada sebelumnya sebagai bagian dari data BALITAROT. Data yang sudah dimiliki setiap instansi yang terlibat ditransformasi agar sesuai dengan format data yang digunakan sistem, seperti yang terlihat pada gambar 6. Demi menjamin terpenuhinya hak instansi perihal kepemilikan data, nota kesepahaman yang jelas dan mengikat harus dibuat.

TABEL I

PERBAIKAN STRUKTUR ALAM BERDASARKAN PRINSIP FENG

\begin{tabular}{|c|c|c|c|}
\hline \multicolumn{4}{|c|}{ SHUI [3] } \\
\hline $\begin{array}{l}\text { Bentuk } \\
\text { Objek }\end{array}$ & Positif & Negatif & $\begin{array}{l}\text { Eko- } \\
\text { Teknologi }\end{array}$ \\
\hline \multicolumn{4}{|l|}{ Memiliki } \\
\hline Bentuk: & & & \\
\hline \multirow{2}{*}{$\begin{array}{l}\text { Gunung } \\
\text { dengan } \\
\text { banyak } \\
\text { tanaman }\end{array}$} & Landai & Curam & $\begin{array}{l}\text { Penanaman } \\
\text { Pohon }\end{array}$ \\
\hline & Rata & Tidak Rata & \\
\hline \multirow[t]{3}{*}{ Aliran } & Bersih & Pekat & Membuat \\
\hline & Perlahan & Cepat & $\begin{array}{l}\text { Belokan } \\
\text { Membuat } \\
\text { Habitat }\end{array}$ \\
\hline & Berbelok & $\begin{array}{l}\text { Lurus dan } \\
\text { Kecil }\end{array}$ & \\
\hline \multirow[t]{2}{*}{ Jalan } & Horisontal & Vertikal & Terbuka \\
\hline & Berbelok & Langsung & $\begin{array}{l}\text { Jembatan } \\
\text { Alamiah } \\
\text { Jalan } \\
\text { Alamiah }\end{array}$ \\
\hline Hutan & Renggang & Padat & $\begin{array}{l}\text { Penanaman } \\
\text { Pohon } \\
\text { Penahan } \\
\text { Angin }\end{array}$ \\
\hline \multirow{4}{*}{$\begin{array}{l}\text { Topografi } \\
\text { Tanah }\end{array}$} & Datar & Berbukit & \\
\hline & Padat & Basah & \\
\hline & Lembut & Kering & \\
\hline & Subur & Tererosi & \\
\hline \multirow{3}{*}{$\begin{array}{l}\text { Tidak } \\
\text { berbentuk: } \\
\text { Air }\end{array}$} & & & \\
\hline & Bersih & Tercemar & \\
\hline & Kering & Lembab & \\
\hline Arah & Terang & Gelap & \\
\hline Temperatur & Hangat & Dingin & \\
\hline
\end{tabular}




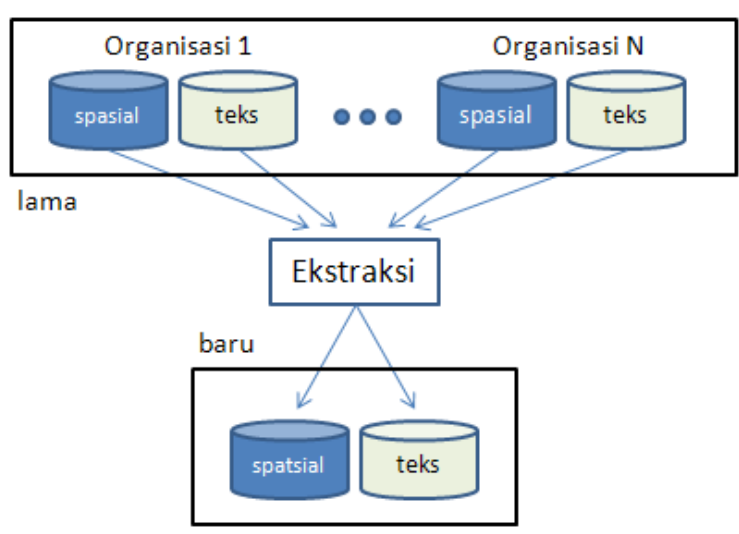

Gambar 6. Penggabungan basis data yang sudah ada.

Perencanaan Berkelanjutan (Continual Planning): Nabil Sahli dan Bernard Moulin [5] membahas framework EKEMAS (Enhanced Knowledge Environment Multi-Agent System), yaitu sebuah framework yang dapat digunakan untuk membangun lingkungan simulasi yang adaptif terhadap kondisi dunia nyata, menggunakan Agen, dan mendukung perencanaan berkelanjutan. EKEMAS sangat cocok digunakan untuk perencanaan penyelamataan pada bencana yang sensitif terhadap waktu. Pada penelitian ini, EKEMAS diuji pada kasus pemadaman kebakaran hutan. Teknik yang digunakan dalam pemadaman adalah memadamkan secara tidak langsung. Teknik ini bertujuan untuk meminimalkan bahan yang dapat memperbesar api. Hal ini sulit karena adanya faktor lingkungan yang kompleks dan dinamis serta tidak dapat diduga. Kondisi di lapangan akan sangat mempengaruhi keputusan yang diambil.

Banyak konsep dan desain dalam EKEMAS yang dapat diadopsi untuk pengembangan BALITAROT. Gambar 7 adalah salah satu hal yang dapat diadopsi. Gambar tersebut menunjukkan arsitektur EKEMAS. Pada EKEMAS sistem diusahakan agar terus menyerupai kondisi dunia nyata. Dunia dalam sistem disebut dunia simulasi, pada gambar 7 dinyatakan dengan label "EKEMAS". Bagian paling bawah adalah pemodelan informasi spasial lapangan dunia nyata. Pada pemodelan ini, sistem menyimpan tingkat kemiringan dan ketinggian tanah. Data tersebut akan berpengaruh pada rencana yang digunakan untuk memadamkan api. Dua lapisan di atas pemodelan spasial adalah pemodelan faktor dinamis di alam dan pemodelan Agen-Agen. Keduanya memanfaatkan data yang tersedia pada pemodelan spasial. Adanya pemodelan ini membuat EKEMAS mampu memperhitungkan kondisi spasial dalam simulasinya. Simulasi dapat digunakan untuk menilai efektifitas rencana yang dibuat.

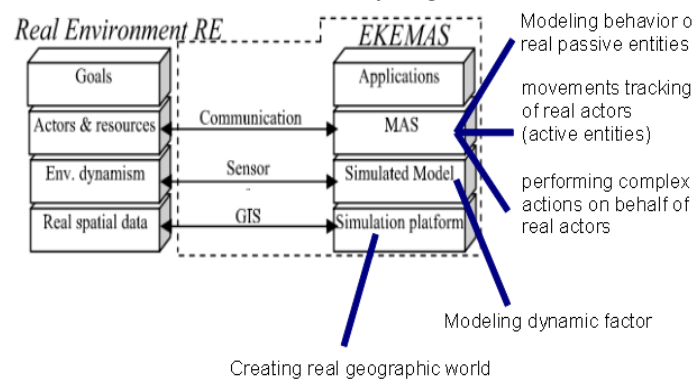

Gambar 7. Arsitektur EKEMAS [5].

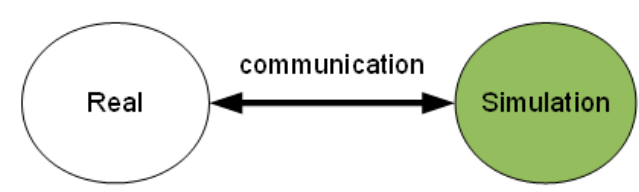

Gambar 8. Konsep komunikasi untuk perencanaan berkelanjutan.

Setiap lapisan di bawah lapisan aplikasi selalu memiliki hubungan dengan dunia nyata. Setiap Agen yang ada selalu dapat berkomunikasi dengan Agen di dunia nyata. Dunia simulasi dalam EKEMAS dibuat berdasarkan pengamatan kondisi di lapangan. Secara sederhana, dapat dikatakan bahwa EKEMAS mencoba membuat dunia simulasi dan nyata berkomunikasi dengan memanfaatkan teknologi nirkabel. Mekanisme inilah yang menyebabkan simulasi selalu dapat menampilkan kondisi terbaru di lapangan. Sistem terus memperbaharui datanya berdasarkan informasi dari sensor dan Agen di lapangan. Faktor komunikasi dan keterbaharuan kondisi lapangan inilah yang memegang peranan penting dalam keberhasilan perencanaan berkelanjutan. Ilustrasi dari konsep komunikasi untuk perencanaan berkelanjutan dapat dilihat pada gambar 8 .

Pada EKEMAS, Agen secara aktif mengirimkan kondisi di lapangan pada sistem. Sementara itu, sistem juga akan secara aktif mengirimkan rencana-rencana terbaru pada Agen. Gambar 9 memperlihatkan konsep ini dengan jelas. Selain itu, setiap Agen di dunia nyata memiliki sensor untuk memperkirakan posisi absolutnya. Posisi absolut ini akan membantu dalam menentukan posisi Agen pada dunia simulasi.

Pada sistem BALITAROT, konsep pemodelan spasial dan Agen-Agen di dunia nyata dapat diadaptasi. Begitu juga dengan konsep komunikasi antara sistem dengan dunia nyata secara autonom. Perencanan berkelanjutan pada BALITAROT juga menjadi salah satu unsur 
penting untuk pengawasan lingkungan. BALITAROT juga diharapkan dapat menjadi sebuah aplikasi simulasi yang dapat digunakan untuk melakukan verifikasi awal terhadap rancangan tata ruang kota. Sebagai contoh dengan menambahkan nilai faktor tingkat penyerapan air dan luas tanah untuk penyerapan air, sistem dapat melakukan simulasi kemungkinan terjadinya banjir. Simulasi ini akan dijalankan pada rancangan tata ruang yang dibuat. Pada data spasial dapat dilihat aliran air dan daerah-daerah yang rawan akan banjir. Kemampuan inilah yang membuat fungsi simulasi diharapkan dapat membantu perancangan tata ruang kota yang lebih baik.

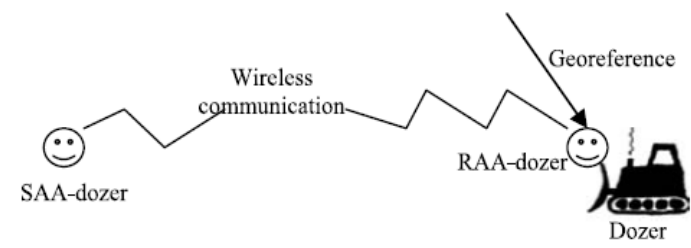

Gambar 9. Komunikasi antara Agen dalam simulasi dan dunia nyata [5]

\section{Hasil dan Pembahasan}

BALITAROT dirancang agar dapat digunakan oleh banyak pihak, baik instansi pemerintah, lembaga independen, atau khalayak umum. Tidak tertutup kemungkinan akan ada banyak pihak yang terlibat dalam pengembangannya. Pembahasan pada bagian ini mengasumsikan keterlibatan lebih dari satu intitusi atau organisasi pada pengembangan BALITAROT.

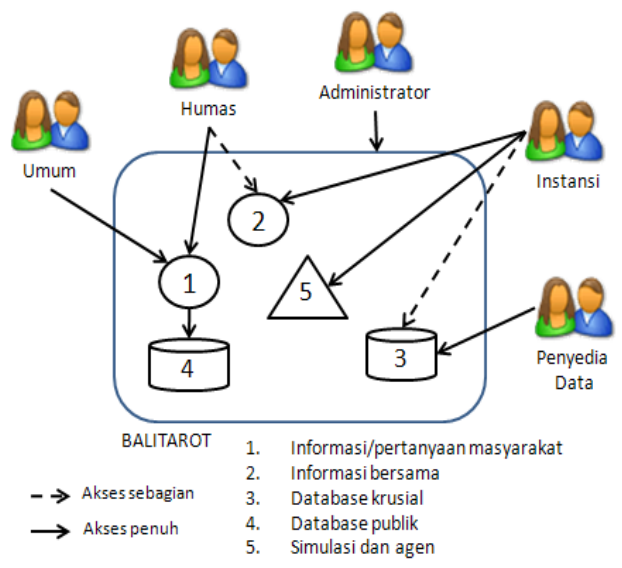

Gambar 10. Pengguna dan haknya dalam sistem BALITAROT.

Pengguna Sistem: Pengguna sistem BALITAROT dapat berasal dari pemerintah atau institusi independen. Institusi yang akan terlibat besar adalah Departemen Dalam Negeri sebagai penyedia data utama dan Badan Pengkajian dan Penerapan Teknologi (BPPT). Terwujudnya BALITAROT menunjukkan tersedianya data spasial Indonesia yang dapat dimanfaatkan oleh banyak pihak. Tersedianya data spasial memungkinkan analisa berdasarkan sudut pandang spasial yang akan membuka sudut pandang baru. Jika dilihat dari kemampuan lain yang dimiliki sistem, maka instansi seperti Departemen Pertahanan, Departement Perindustrian dan Perdagangan, Departemen Pertanian, Departemen Kehutanan, Departemen Perhubungan, Departemen Kebudayaan dan Parawisata, dan Departemen Komunikasi dan Informatika juga akan turut merasakan pengaruh adanya BALITAROT.

Departemen Pertahanan: Bersama-sama Departemen Pertahanan, TNI, dan Polri dapat menganalisa kekuatan pertahanan di tiap daerah. Melihat tingkat kemungkinan terjadinya hal-hal yang tidak diinginkan pada wilayah-wilayah tertentu. Sistem juga dapat digunakan untuk merancang skenario penyelamatan atau pertahanan. Sangat mungkin untuk membuat peta pola kejahatan atau ancaman untuk melihat trend tindak kejahatan. Departemen Pertahanan dapat memanfaatkan BALITAROT untuk memantau dan menangani penyelundupan, illegal fishing, dan illegal logging.

Departemen Perindustrian dan Perdagangan: Departemen ini mempengaruhi pembuatan rancangan tata ruang wilayah.

Departemen Pertanian: Fungsi simulasi dapat dimanfaatkan untuk memperkirakan efektifitas sistem irigasi, pola penyebaran hama, penyebaran pupuk dan bibit, serta skenario untuk mengatasi kekeringan. Simulasi juga dapat dimanfaatkan untuk memperkirakan banyaknya lahan pertanian yang perlu dibuka untuk memenuhi kebutuhan pangan dalam negeri.

Departemen Kehutanan: Mekanisme komunikasi dan simulasi akan dapat banyak membantu pengawasaan di hutan. Selain itu BALITAROT dapat membantu perencanaan penanggulanganbencana kebakaran hutan seperti yang dijelaskan dalam [5] dan pemantauan illegal logging.

Departemen Perhubungan: Sistem dapat digunakan untuk melakukan simulasi tingkat kepadatan jalan pada daerah dan waktu tertentu. Kemampuan komunikasi sistem bahkan dapat dimanfaatkanuntuk mengatasi hal tersebut dengan mengaturarus kendaraan. Sistem juga dapat dimanfaatkan untuk melihat apakah transportasi masal yang tersedia saat inisudah mencukupi. 
Departemen Kebudayaan dan Pariwisata: Departemen ini dapat membantu pengembangan kota-kotadi Indonesia menjadi kota wisata.

Departemen Komunikasi dan Informatika: Departemen ini akan mempengaruhi kemampuan komunikasi yang dimiliki sistem.Banyaknya instansi yang terlibat akan memunculkan variasi kebutuhan terhadap sistem. Kebutuhan ini harus bisa dipenuhi tanpa menggangu stabilitas sistem. Tingkat kepercayaan data yang disediakan harus selalu dijaga. Untuk itu, pengguna sistem dibedakan berdasarkan lima kelompok seperti pada gambar 10, yaitu penyedia data, instansi atau organisasi, administrator, humas, dan umum.

Penyedia Data: Kualitas data yang tersedia harus terjamin. Untuk itu diperlukan suatu mekanisme sehingga sistem dapat memperkecil kemungkinan munculnya data-data yang tidak benar. Data yang ada dalam sistem merupakan hasil penggabungan data pada sistem-sistem sebelumnya. Untuk itu harus dipastikan bahwa basis data dari sistem sebelumnya tidak terganggu dengan BALITAROT. Untuk itu penyediaan dan pembaharuan data diserahkan sepenuhnya kepada penyedia data. Mekanisme seperti ini menuntut adanya komitmen dari penyedia data. Penyedia data juga dapat bertindak sebagai pengguna tingkat instansi.

Instansi atau Organisasi: Pengguna instansi merupakan instansi atau organisasi yang membutuhkan data dari sistem untuk melakukan analisa. Pengguna dengan tipe ini diharapkan dapat turut berkolaborasi dalam membuat perencanaan tata ruang kota. Instansi dapat memanfaatkan fungsi simulasi dan informasi bersama yang tersedia dalam sistem.

Administrator: Bertugas melakukan pengawasan kinerja dan pemeliharan sistem. Administrator memiliki akses untuk membaca log sistem dan menganalisa komponen sistem yang perlu ditingkatkan. Peningkatan ditujukan agar sistem dapat memberikan layanan yang lebih baik.

Humas: Bertugas membaca dan menyeleksi informasi yang diterima dari khalayak umum. Jika informasi tersebut bermanfaat maka humas meneruskan informasi tersebut pada pihak terkait. Humas juga bertanggungjawab menjawab pertanyaan dan memberikan informasi yang benar kepada khalayak umum.

Umum: Pengguna umum adalah seluruh orang yang memiliki akses ke sistem. Pengguna dapat memperoleh informasi teks dan spasial yang sifatnya publik.

Pembagian lima jenis pengguna secara umum ditujukan agar pembagian tugas menjadi lebih jelas. BALITAROT dapat berjalan dengan baik apabila setiap pengguna sistem melakukan tugasnya dengan baik. Contoh sederhana adalah jika pengguna dengan tipe penyedia data tidak melakukan perkerjaannya, maka data-data yang tersedia dalam sistem bukanlah data terbaru. Hal ini akan menyebabkan perencanaan yang dilakukan tidak dapat langsung diterapkan di lapangan.

Perbedaan kebutuhan analisa untuk setiap instansi dapat ditangani dengan mengembangkan simulasi dan Agen yang sesuai dengan kebutuhan instansi tersebut. Pengembangan simulasi dan Agen tidak akan banyak menuntut perubahan pada dunia virtual. Hal ini karena arsitektur sistem dikembangkan seperti yang ditunjukkan pada gambar 14.

Pengumpulan dan Pengolahan Data: Terdapat dua jenis data yang digunakan dalam sistem BALITAROT, yaitu data spasial dan data non-spasial. Hal ini serupa dengan yang digunakan dalam [4]. Data spasial dapat berupa hasil pencitraan satelit atau peta. Data spasial diharapkan dapat dilihat dalam berbagai tingkat detail. Foto-foto dapat ditambahkan pada beberapa tempat yang menjadi pusat kerumunan massa atau tempat penting.

Data non-spasial dapat beraneka ragam jenisnya dan tergantung pada kebutuhan. Jika sistem ini sudah dimanfaatkan banyak pihak, maka akan semakin terlihat variasi data yang diperlukan. Namun ada beberapa data penting yang harus tersedia, yaitu luas wilayah, jumlah penduduk, jumlah kepala keluarga, dan pendapatan rata-rata. Data ini harus tersedia dalam berbagai tingkatan, berdasarkan pulau, propinsi,dan daerah. Selain itu data ketinggian dan kemiringan tanah, fasilitas yang tersedia di setiap kota, perbatasan wilayah tiap daerah dan pejabat-pejabat pemerintah di seluruh daerah. Kemudian kebijakan pembangunan di Indonesia dan tiap wilayah, daftar fasilitas-fasilitas minimum yang harus tersedia dalam sebuah kota juga kekayaan alam dan budaya yang dimiliki oleh suatu daerah.

Database yang tersedia

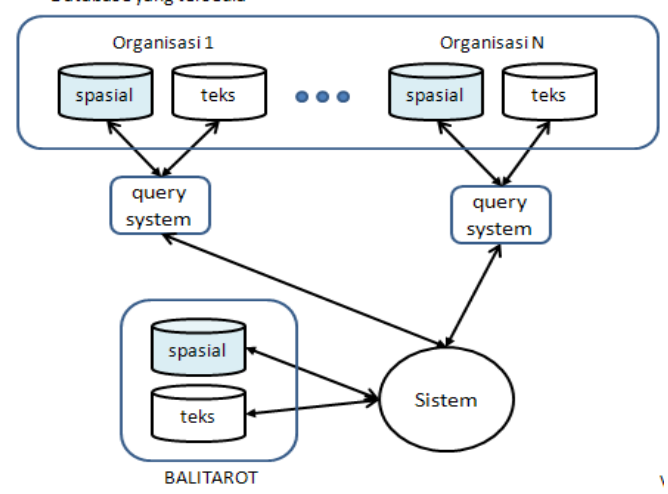

Gambar 11. Penggabungan basis data yang sudah ada dalam BALITAROT. 
BALITAROT dibuat agar dapat menggunakan data yang sudah tersedia dalam sistem-sistem yang sudah ada sebelumnya. Hal ini dapat mempermudah pengumpulan dan pemanfaatan data. Agar data-data pada sistem sebelumnya dapat dimanfaatkan, perlu mekanisme agar BALITAROT dapat berkomunikasi dengan data tersebut. Salah satu cara yang dapat digunakan adalah cara yang diusulkan dalam [4], lihat gambar 6. Cara tersebut dapat menjamin bahwa data yang dimiliki institusi asal tidak terganggu oleh BALITAROT. Namun cara seperti ini membuat mekanisme pembaharuan harus dilakukan dua kali, pembaharuan pada sistem institusi dan BALITAROT. Cara kedua adalah dengan mengikuti skema pada gambar 11. Pada cara ini, ada waktu yang harus diluangkan untuk membuat sebuah sistem query untuk mengakses basis data yang sudah ada. Sistem query dapat mengatur hak akses dan tabel-tabel yang dibuka untuk BALITAROT. Proses pembaharuandata cukup dilakukan sekali. Jika terjadi perubahan struktur basis data pada sistem milik instansi, maka cukup dilakukan penyesuaian pada sistem query. BALITAROT juga memiliki basis data tersendiri untuk menjaga agar BALITAROT tidak mengganggu data aslinya.

Untuk memenuhi prinsip perencanaan berkelanjutan sesuai dengan [5], informasi dalam sistem harus diperbaharui secara berkala. Siklus pembaharuan data untuk kedua jenis data tersebut mungkin tidak akan sama. Siklus pembaharuan data non-spasial akan lebih cepat dari siklus pembaharuan data spasial. Setiap data yang diberikan dalam sistem harus dapat terjamin kebenarannya. Maka dari itu, cara paling tepat adalah dengan menyerahkan tanggung jawab pembaharuan ini kepada instansi yang menyediakan data tersebut. Jika ada masyarakat atau instansi lain yang memiliki informasi, humas akan meneruskan informasi tersebut instansi yang bertanggungjawab. Jika ada salah satu masyarakat yang memberikan informasi dengan tepat dan berkala, maka pemberi informasi dapat diangkat sebagai kontributor independen dan diberikan hak lebih dalam sistem.

Cara lain yang dapat digunakan untuk memperoleh kondisi terbaru di lapangan adalah dengan memasang kamera-kamera pengawas di beberapa titik. Kamera akan mengamati kondisi bangunan atau lapangan. Gambar yang ditangkap melalui kamera dapat dikirimkan ke sistem melalui sambungan nirkabel. Pemanfaatan jaringan nirkabel yang sudah tersedia dapat dilakukan dengan mengajak perusahaan telekomunikasi pemerintah, Telkomsel. Telkomsel sampai saat ini sudah menjangkau area komunikasi yang sangat luas. Gambar 12 memperlihatkan ilustrasi pemanfaatan kamera dalam sistem. Ilustrasi tersebut dibuat dibuat dengan menggunakan gambar dari Google Map dan foto yang diambil dari jembatan penyebrangan Bendhil. Terlihat pada peta terdapat tiga buah kamera pada lokasi berbeda, yaitu daerah yang ditandai dengan kotak berwarna putih atau merah. Kotak yang berwarna merah menunjukan kamera yang sedang diakses oleh pengguna. Pada tahun 2009 bulan September, teknologi seperti ini sudah digunakan untuk membantu para pemudik dalam menentukan jalur perjalanan mereka.

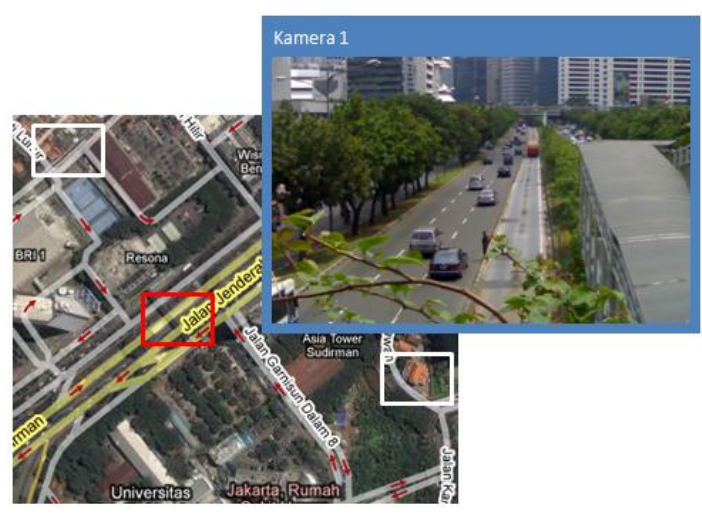

Gambar 12. Ilustrasi visualisasi pengamatan dengan kamera.

Data spasial yang dimiliki sistem dapat ditampilkan dalam bentuk berlapis (layer). Gambar 13 memperlihatkan bagaimana sistem menyimpan dan menampilkan data tersebut. Pada bagian dengan label layer, sistem dapat memanfaatkan tiga buah layer untuk merepresentasikan informasi bawah tanah. Namun sistem dapat menambahkan layer sebanyakbanyaknya untuk merepresentasikan informasi di atas permukaan tanah.

Data spasial yang dimiliki sistem dapat ditampilkan dalam bentuk berlapis (layer). Gambar 13 memperlihatkan bagaimana sistem menyimpan dan menampilkan data tersebut. Pada bagian dengan label layer, sistem dapat memanfaatkan tiga buah layer untuk merepresentasikan informasi bawah tanah. Namun sistem dapat menambahkan layer sebanyakbanyaknya untuk merepresentasikan informasi di atas permukaan tanah.

Perjanjian Kerja Sama: Konsep kolaborasi dan kerja sama sangat penting dalam pengembangan dan pemanfaatan sistem BALITAROT. Perlu diadakan suatu kesepakatan dan kesepahaman antara institusi-institusi yang terlibat. Isi kesepahaman berupa etika dalam pemanfaatan data sistem dan pembagian peran. Perjanjian kerja sama dengan perusahan 
telekomunikasi juga harus dipersiapkan. Kemudian institusi pendidikan dapat diajak bekerja sama untuk melakukan penelitian terkait kebutuhan pada sistem.

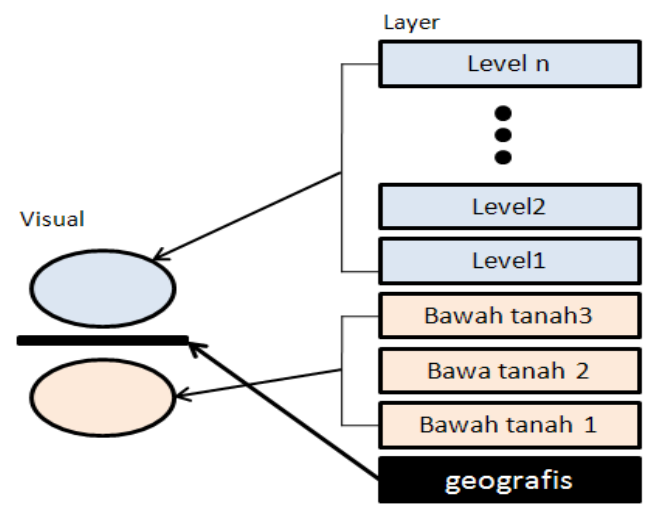

Gambar 13. Visualisasi dan penyimpanan layer dalam BALITAROT.

Arsitektur dan Fungsi Sistem: Arsitektur yang akan diimplementasikan dalam sistem BALITAROT dapat dilihat pada gambar 14 . Model ini merupakan hasil adaptasi dari arsitektur yang diajukan dalam [5]. Model dunia virtual dibuat dengan memanfaatkan data spasial yang disediakan beberapa institusi. Pemodelan tahap pertama ini hanya merupakan representasi ulang dari pembacaan data spasial. Selanjutnya sistem menggunakan teknik pembuatan cluster untuk menentukan jenis-jenis objek pada data tersebut. Hal ini akan memberikan sebuah layer jenis-jenis objek yang dapat digunakan pengguna.

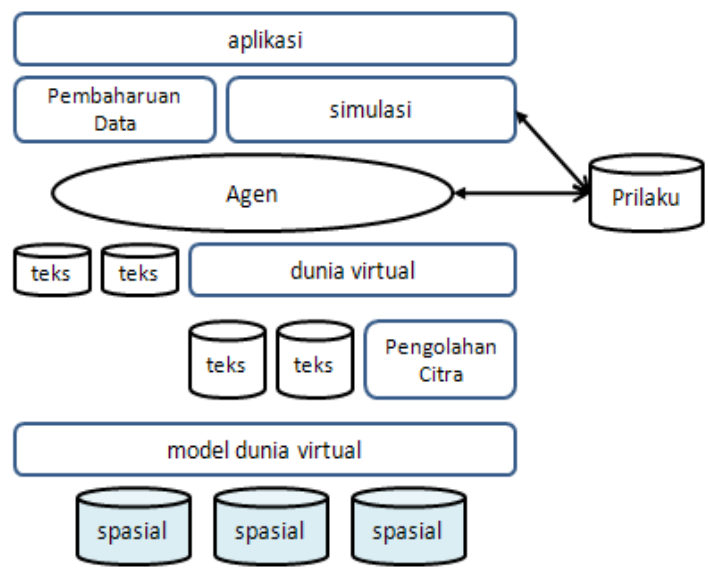

Gambar 14. Arsitektur Sistem BALITAROT.

Penentuan jenis suatu objek akan bergantung pada tingkat detail yang dibutuhkan oleh pengguna. Hal ini akan menimbulkan variasi yang sangat luas, untuk itu perlu dibangun ontologi yang dapat mengakomodasi perbedaan ini. Cara sederhana yang mungkin dilakukan adalah dengan menggunakan ontologi bertingkat. Gambar 15 memperlihatkan penggunaan ontologi dalam BALITAROT. Ontologi dibagi dalam beberapa tingkatan di mana ada ontologi yang menggunakan konsep-konsep yang dimiliki oleh ontologi tingkat lainnya. Sistem ini menggunakan teknik ontologi dasar (share ontology). Ontologi dasar adalah konsep-konsep yang dapat digunakan oleh ontologi yang lebih kompleks. Penggunaan ontologi dasar ini akan memungkinkan kemudahan pembuatan konsep-konsep baru sesuai dengan kebutuhan setiap bidang.

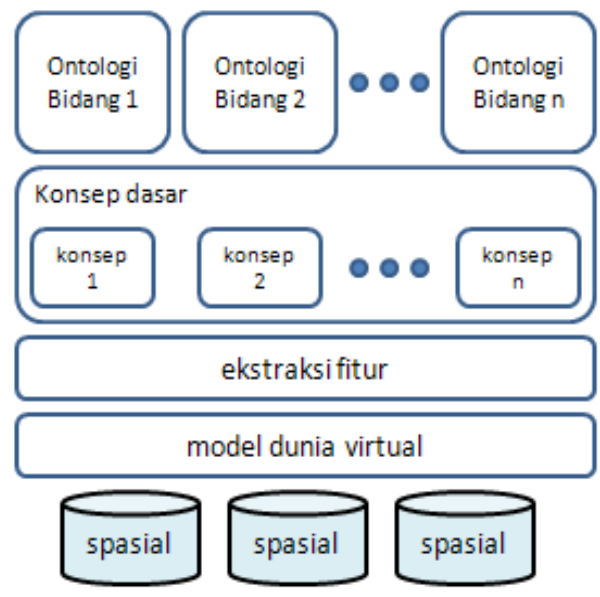

Gambar 15. Penggunaan konsep ontologi dalam BALITAROT.

Kembali pada penjelasan mengenai arsitektur sistem, model awal selanjutnya digabungkan dengan data tekstual untuk memperkaya informasi data spasial. Hasil penggabungan antara data tekstual dan spasial, serta pengolahan citra terhadap data spasial ini disebut sebagai dunia virtual. Hal ini mengikuti konsep yang diajukan pada framework EKEMAS. Lapisan di atas dunia virtual adalah Agen. Agen pada sistem ini adalah sebuah mekanisme autonom yang dapat dimanfaatkan untuk melakukan pencarian dalam dunia virtual, pencarian dalamdata tekstual, perhitungan simulasi, dan berkomunikasi dengan Agen di dunia nyata. Prilaku Agen akan tergantung dari fungsi masing-masing. Prilaku Agen akan berkaitan dengan ontologi dan jenis aplikasi yang dikembangkan. Agen juga berperan penting dalam perencanaan berkelanjutan agar dapat berjalan dengan baik. Hal ini dikarenakan Agen dapat mengakses keadaan terkini pada dunia nyata. Semua informasi prilaku dapat dibaca dari basis data prilaku. Lapisan di atas Agen adalah mekanisme simulasi dan pembaharuan data. Lapisan di atas lapisan Agen membutuhkan kemampuan Agen agar dapat berfungsi dengan baik. 
Salah satu fungsi sistem yang telah disebutkan adalah membantu dalam perancangan tata ruang kota. Gambar 16 merupakan salah satu ilustrasi bagaimana sistem membantu kegiatan perancangan. Gambar 16 memperlihatkan informasi yang muncul ketika pengguna sedang merancang tata ruang sebuah kota. Bagian informasi menampilkan daftar fasilitas minimal yang harus tersedia. Fasilitas yang diberi warna merah adalah fasilitas penting yang belum tersedia. Pada gambar dapat dilihat bahwa pada Rumah Sakit diberikan warna merah dan diikuti dengan angka nol. Hal ini menunjukkan bahwapada kota Bayangan belum ada rumah sakit yang dibangun dan hal ini di bawah standar fasilitas minimum yang harus dimiliki sebuah kota. Informasi yang dapat ditunjukkan dengan data spasial akan jauh lebih kaya.

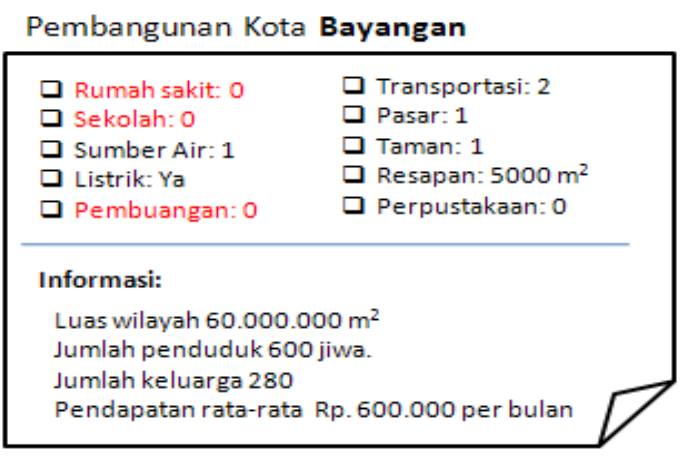

Gambar 16. Informasi yang muncul saat merancang kota.

\section{Kesimpulan}

Pengembangan sistem BALITAROT dapat membawa banyak manfaat bagi Indonesia. Sistem ini dapat digunakan untuk membantu perencanaan tata ruang kota dan perbaikan lingkungan. Penyediaan data spasial pada sistem dapat digunakanuntuk menyimpan peta pipa air bawah tanah, jaringan komunikasi, jaringan listrik, sumber daya alam, serta penyebaran binatang dan tanaman. Selain sebagai sebuah sistem informasi spasial, sistem juga dikembangkan menjadi sebuah alat simulasi. Fungsi simulasi dapat digunakan untuk membantu dalam menguji tata ruang kota dan penanggulangan bencana. Simulasi dapat membantu memperkirakan kemampuan kota dalam menghadapi hujan besar atau kemacetan.

Pengembangan sistem BALITAROT bukan suatu hal yang tidak mungkin. Penelitianpenelitian sebelumnya sudah memberikan landasan yang memadai untuk digunakan dalam pengembangan sistem. Pengembangan sistem memang akan membutuhkan waktu yang lama karena sebagian besar fungsi yang dibutuhkan masih bersifat riset. Namun hal tersebut akan lebih mudah diatasi jika rencana kerja sama berhasil dijalankan.

\section{Referensi}

[1] Badan Pusat Statistik Indonesia, Tingkat Kemiskinan di Indonesia Tahun 2005-2006, Jakarta, 2006.

[2] Situs resmi pemerintah Indonesia, http://www.indonesia.go.id/id/index.php?opt ion=com_content\&task=view\&id=121\&Ite mid=1716, retrieved May 18, 2008.

[3] S. Hong, I. Song, \& J. Wu, "Fengshui Theory in Urban Lanscape Planning, ' Urban Ecosystems, vol. 10, pp. 221-237, 2006.

[4] M.A. Fulazzaky \& H. Akil, "Development of Data and Information Center System to Improve Water Resources Management in Indonesia," Water resource Management, vol. 25, pp. 1055- 1066, 2008.

[5] N. Sahli \& B. Moulin, "EKEMAS - an Agent-Based Geosimulation Framework to Support Continual Planning in the Real World," Applied Intelligence, vol. 31, pp. 188-209, 2008.

[6] T. Connors, How Feng Shui Works, HowStuffWorks, http://people.howstuffworks.com/fengshui.htm, retrieved March 11, 2009.

[7] Publikasi perbaikan lingkungan di Korea, http://www.metro.seoul.kr/kor2000/chungae home/en/seoul/main.htm, retrieved March 11, 2009. 